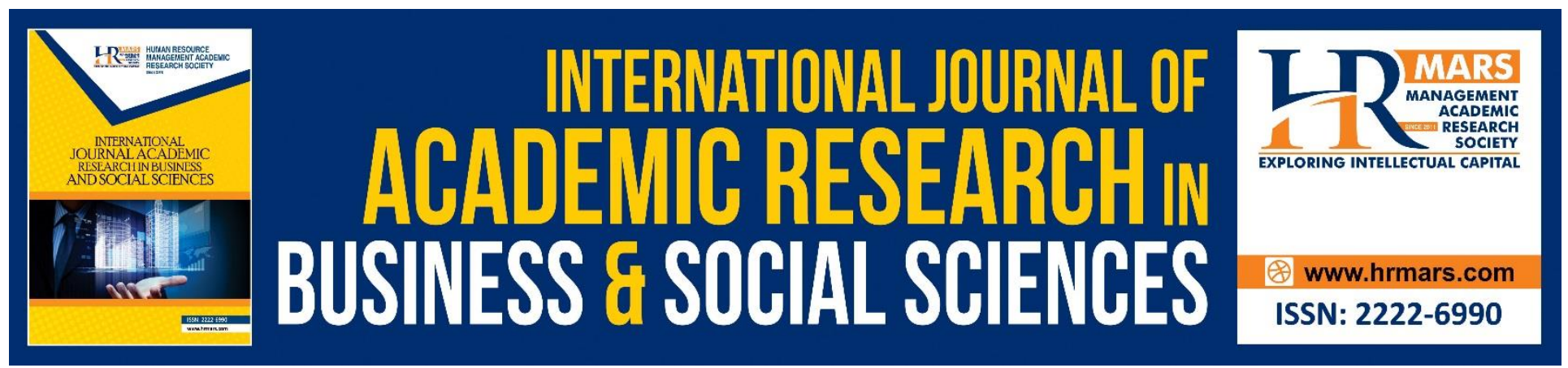

\title{
The Influence of Media in the Involvement of Youth with ISIS Movement in Malaysia
}

Siti Rokiah Ab Rahman, Fadzli Adam, Fakhratu Naimah Muhad

To Link this Article: http://dx.doi.org/10.6007/IJARBSS/v8-i11/4962

DOI: $10.6007 /$ IJARBSS/v8-i11/4962

Received: 03 Oct 2018, Revised: 19 Oct 2018, Accepted: 06 Nov 2018

Published Online: 19 Nov 2018

In-Text Citation: (Rahman, Adam, \& Muhad, 2018)

To Cite this Article: Rahman, S. R. A., Adam, F., \& Muhad, F. N. (2018). The Influence of Media in the Involvement of Youth with ISIS Movement in Malaysia. International Journal of Academic Research in Business and Social Sciences, 8(11), 857-865.

Copyright: (C) 2018 The Author(s)

Published by Human Resource Management Academic Research Society (www.hrmars.com)

This article is published under the Creative Commons Attribution (CC BY 4.0) license. Anyone may reproduce, distribute, translate and create derivative works of this article (for both commercial and non-commercial purposes), subject to full attribution to the original publication and authors. The full terms of this license may be seen

at: $\underline{\text { http://creativecommons.org/licences/by/4.0/legalcode }}$

Vol. 8, No. 11, 2018, Pg. 857 - 865

http://hrmars.com/index.php/pages/detail/IJARBSS

JOURNAL HOMEPAGE

Full Terms \& Conditions of access and use can be found at http://hrmars.com/index.php/pages/detail/publication-ethics 


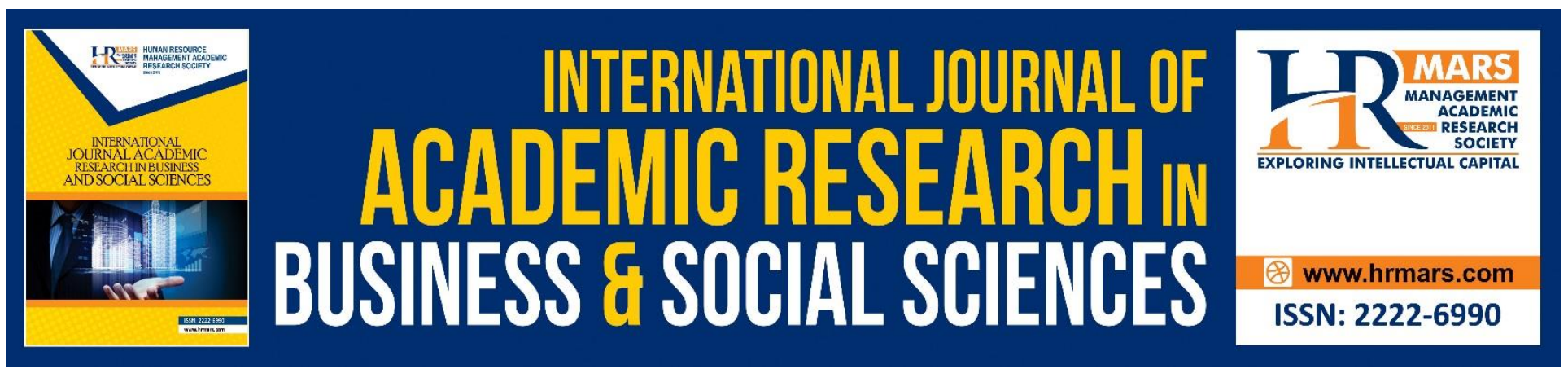

\title{
The Influence of Media in the Involvement of Youth with ISIS Movement in Malaysia
}

\author{
Siti Rokiah Ab Rahman, Fadzli Adam, Fakhratu Naimah Muhad \\ Research Institute for Islamic Products and Malay Civilization (INSPIRE), Universiti Sultan Zainal \\ Abidin, Terengganu, Malaysia \\ *Corresponding Author: fadzliadam@unisza.edu.my
}

\begin{abstract}
The power of media as a medium of communication and dissemination of ideology has been fully utilized by Islamic State of Iraq and Syria (ISIS) militant movement to strengthen its position. Malaysia has no exception in receiving the ideology of the movement which is claimed to be contrary to Islamic law. There were several categories of Malaysians especially youth affected by the movement and some of them were willing to migrate to Syria to join the fight against ISIS enemies. Their mind and action have greatly been influenced by the power of media and its technology in attracting the agenda of terrorism. Therefore, it is the purpose of this research to study the influence of media on Malaysian youth involvement in ISIS movement. This research uses document analysis and past researches as sources of data collection. The finding shows that media has significantly influenced the thinking and action of its users especially among the youth with the dissemination of news and information provided by ISIS. This research is expected to contribute to the government policies in order to eradicate the ISIS movement threats. Besides, this research is also expected to assist the Malaysian Communications and Multimedia Commission (MCMC) in analyzing the proper approach to counter cyber-attack from damaging the mindset and involvement of youth in ISIS.
\end{abstract}

Keywords: Media, ISIS movement, Youths

\section{INTRODUCTION}

The world nowadays facing a serious threat from extremism and radicalism due to several factors including misunderstanding the teaching of Islam and being fanatic in certain ideologies (Adam and Muhad, 2017). The spread of radical movement and religious extremism has evolved to ASEAN region in the 1990s which centered in Indonesia and later on moved to Southern Thailand as the main training area and the group's cadres. In addition, Philippines was reported to be the area of the extremist movement that gives negative impact on the region.

Malaysia also cannot escape from receiving the ideology of this movement. The radical and extremist movement based on the religion was a hot issue which has been discussed at length at the Malaysian 
Parliament. The sixth Prime Minister of Malaysia, The Honourable Dato' Seri Mohd Najib Tun Abdul Razak presented the White Paper at the Parliament as a serious effort to eliminate the threats of this terrorist group. According to (Juergensmeyer, 2017) most of the world's major religions which are Christians, Jews, Hindus, Sikhs, Muslims and Buddhists have dark history in the context of religious extremism. For example in Myanmar, the apartheid phenomenon has shockingly strike the worldwide sense of humanity for the massive cruelty genocide pictured by the media, the increasing numbers of refugees in the nearest countries, the neglection of other governments to give shelter and welfare (Fadzli Adam, Muhad, Wahid, and Mansor, 2017).

The development of globalization has increased the threats of religious extremism to a larger scale. One of the radical and extreme movements which had gained attention globally in the world community is the Islamic State (IS). The group named itself as Islamic State or IS, Islamic State of Iraq and Syria (ISIS), Islamic State of Iraq and The Levant (ISIL) or Daesh that promote the mission to dominate province in order to create an Islamic caliphate. Their intention to form such caliphate is through the methods of jihad based on the understanding and ideology that is contrary to the Islamic law. This movement shocks the whole world when it is linked to suicide bombing in public places, detonation of self and others, mental and physical abuse against those who are not with them and recruitment of young children and youths (Gorawantschy, Gunaratna, Sarmah and Rueppel, 2016). In essence, these extremists do not portray the true glory of Islam that prevents its followers from acting beyond the boundaries of humanity. This activity is further enhanced with the development of internet technology that enables this movement to convey the ideology and recruit members online. This group is actively running the jihad propaganda campaigns via cyber such as social media, social networks, websites and others.

According to reports from the Chief Assistant Director of the Counter-Terrorism Division, Bukit Aman Special Branch SAC Datuk Ayub Khan Mydin Pitchay, a total of 61 Malaysians were spotted in Syria for joining the IS militant groups. Out of these numbers, 10 women are identified and the latest catches of suspects have reached 71 people (Suara TV, March 2015). Furthermore, local media have reported a case of two Malaysians who have detonated their own self for the fight with Daesh terrorist (Malaysiandigest.com, 2016). It is very worrying that Youth involvement with ISIS movement in Malaysia keeps on rising. They have not really understood actual reason of their involvement and their objectives are unclear. Surprisingly, some of the youth have not really noticed of the negative influence they received from social media. Hence, this research aims to study the influence of media on the involvement of youths with ISIS movement.

\section{THE PHENOMENON AND IJTIHAD OF ISIS MOVEMENT}

Basically, extremism can be defined as an extremist group with certain ideological understanding and threat on others who do not accept their ideology (Horgan, 2005). Extremism that based on religion refers to religious maladjustment caused by certain ideologies and political thoughts. This situation occurs when religious conflicts happen in society which which lead to religious split. This view is in line with (Kanade's, 2016) explanation that the concept of jihad which is born from the combination of political and religious elements can lead to war and conquest. It is common that politics and business activities become great polemic and can lead to the loss of humanity. The aim to have power and the feeling of greed are considered two main factors for any involvement in ISIS that can degrade 
the level of compassionate and benevolent in each man (Muhad et al., 2017). The ISIS movement is seen to use Islamic name to obscure and legalize their plans and actions.

ISIS is perceived as radical group and extremist that exists from Salafi Jihadi movement in Iraq. Originally it consists of three different jihad organizations, in which one of the organization is Ansar al-Islam comprising Iraqi Salafi Jihadi groups that form the distinctive 'Islamic Government' and practice radical Islamic life. Meanwhile, (Tambunan, 2014) stated that this movement is originated from Al-Qaeda which practices aggressive and extreme understanding and ideology. The jihad exclamation and martyrdom in this group is contradicted with the teaching of Islam and can lead to disbelief since they legalize blood among Muslims (Portal Rasmi Fatwa Malaysia 2014). The ISIS movement uses the name of Islam to legalize their plans and actions. The ISIS movement has also manipulated the real concept of jihad in order to achieve their goals and objectives. In this cause, they allow violence and actions beyond humanity such as provocation, threats, violence, abductions, bombings, wars and so on to achieve its mission and goals.

Generally, Muslims are required to put their concentration on both horizontal and vertical realm; transcendence of Allah as the creator and also on the other side of human responsibilities (Fadzli Adam, Muhad, Wahid, Mansor et al., 2017). However, the existence of ISIS has confounded the community including the Muslim community itself. For example, the concept of jihad is misinterpreted by certain individuals as armed warfare to eliminate the elements of disbelief which opposes Islam and its people. In addition, fatwa institution is often misused by the wrong party which gives justification that jihadist must be done by means of violence and coercion. This concept is not just against the non-Islamic kingdom but also against fellow Muslims which is labeled as a pagan kingdom. Moreover, many Islamic scholars have issued various fatwas according to their own ijtihad without basis and religious facts to justify their group's actions. The fatwa from the harsh radical groups such as the permission to kill non-Muslims in the name of jihad and suicide bombing actions has received great attention. Besides, this group also issued a fatwa in order to bring down secular governments according to their own interpretation without clearly understand the real concepts.

\section{THE APPLICATION OF SOCIAL MEDIA BY ISIS MOVEMENT}

This century, social media has become an important medium in the communication process and online information delivery. Social media is also regarded significant to organizations or radical movements especially ISIS because of the movement using this medium completely to convey the propaganda and to recruit new members globally. According to (Pew Research Center January, 2014) stated that youths aged between 18 to 29 years old use the social media platforms such as Facebook, Twitter, and Youtube which allowed propaganda campaigns to across the globe. This is in line with studies by (Jacobson, 2010; Ogun, 2012; Weimann, 2008) which stated that various media was used by militant movements including the internet to disseminate propaganda and as a recruitment instrument for terrorist activities. Postings related to ISIS on internet sites including high-quality videos and images that incorporate visual effects were used by ISIS professionals to promote their ideology. Globalization of communications also had evolved in tandem with the improvement of internet technology as people nowadays attached to use e-mails, smartphones and tablets and other 
technology tools. This phenomenon has changed the structures and capabilities of community in communication. Militant movements are not lag behind in using the internet technology to dominate in publication and gained benefits from the technology that offered a fast, cheap and acts on delivering their political messages, religion or ideology by aiming a wider target on the world frontier (Crilley, 2001).

The ISIS group not only uses the physical operations but also appropriately implementing virtual capabilities to expand its influence. In this century, the internet acts as an important tool to disseminate information for Islamic radical groups (Bräuchler, 2004). Almost 90\% of terrorism associations in cyberspace are rising through social media (Mielach, 2012). During the time civilians began exploring and conflicting with militants groups such as ISIS, this organization more actively initiating the campaign of jihad through cyber by using internet website and social media which focused on youths and the groups that were easily influenced. (Berger, 2014). The usage of cyber technology provided opportunities and benefits to this movement in delivering the ideology and recruiting new members online. This group was actively running the jihad propaganda campaigns via cyber such as social media, social networks, websites and others. They have trained team members and also professional in the use of advanced technology. Organizations that tracked on the acts of terrorists and militant groups in the Middle East and Asia reported that the group has worked for years to become proficient in cyber technology (Maniscalco and Christen 2001). This is proven by the online counter-attack from the ISIS militant group to disseminate its propaganda and make threats to any party who disagrees with their ideology and existence.

This is in line with a study by (York, 2015) which stated that ISIS used the internet network to recruit members, disseminating propaganda and one of the ways to communicate with different cells in the organization. Meanwhile, Sauffiyan, Hassan and Influence (2016) also stated that the use of videos and social media became the latest war of nerve's weapons for militant groups to build influence, recruitment and reinforcing their ideology in the region. The terrorist group not only used social networking site and social media to spread terrorism propaganda but also it is used to monitor and recruiting new members (Marcu and Balteanu, 2014). Other than to propagate understanding and ideology to civilians, they also make threats to leaders or nations that oppose and disapprove of their existence. This is supported by (Walsh, 2015) in which stated that ISIS uses the internet and social media in disseminating propaganda campaign. This movement is the first terrorist group that has ever-growing followers on the internet that makes the internet as an important tool for the group (Hannigan, 2014). Today, to join the extremism and to combat with enemies is no longer necessitate a man to be in physically support and fight on the battlefield. They just have to sit in front of the computer and promoting radical ideology through social media. This is the current strategy to expand and disseminating campaigns through online.

\section{THE INFLUENCE OF MEDIA TOWARDS YOUTH INVOLVEMENT IN IS MOVEMENT}

The development of internet technology gives maximum impact on all aspects of human life, especially to youth or $Y$ generation. According to (Justin, 2010), generation $Y$ is known as those born in technology era between the year 1980 and 2000 . Besides that, generation $Y$ is a digital community that identified as individuals born between 1980 and 1999 (Prensky, 2001). This group uses social 
media to obtain information and find solutions through the information that available in social media. The influence of media has changed the structure of human life which turn them to be too dependent on communication and information through online media.

It is globally accepted that media is the main medium in communications and community relations all over the world. The technological advancement has widened the concept of global terrorism when various parties attempt to describe the meaning and definition of violence based on their own respective political interests. The emergence of new media such as Facebook, Twitter, Blog spot and others has been fully utilized by extremists to spread the ideology speedily and swiftly (Mahan and Griset, 2013). According to (Greene, 2015), extremist organizations including ISIS are aware of the benefits and impacts of media on their struggle and they change their strategy for a sudden political change. The power of media is very relevant and effective in delivering the extremism movement and ideology. Therefore, media users have easily been influenced to involve in the movement. The influence of media is a new challenge to the whole nation as the dissemination of ideology takes place without control from the government.

According to (Alazzany, 2008), after the attacks on the World Trade Center and Pentagon on 11 September 2011 in New York, the majority of the news reported by the New York Times regarding Muslim groups in the United States did not emphasize the difference between moderate group and extremist group. This situation caused the publics and readers interpret information in the way that there was no difference between the Muslim groups and the extremist group. In other words, they simply perceived all Muslim groups are extremists. In the past, media often used human rights and freedom as an excuse for this involvement such as the right in democracy, freedom of speech and individual rights. These rights enabled them to implement their culture, way of life and religion. This situation became worse when the concept of "borderless culture" was introduced and applied in disseminating information. They tended to be more profit-oriented, individualistic and materialistic in technology that makes any individual to decide on their own. Moreover, morality has been neglected in the system of human life where there has been several judgments that need to be emphasized before taking any actions. The revelation, hadith, maqasid syari'iyyah and the true dimension of thinking are among the important elements things to be followed in one's deeds (Abdullah Muhammad Zin, 2017). Therefore, the credibility of information and media is very important as online users with lack of basic religious knowledge tend to access and surf existing unfiltered information by the media.

Although the current education is growing due to the rapid growth of media, at the same time the media also contributes to negative elements (Wan Hamat, Hussin, Mohamed Yusoff and Sapar, 2013). Education is also one of the ways for this extremist movement to spread their da' wah to the youths. This is stated by (Mohd Nasir, 2011) that most of these movements assumed that the education system is damaged because it is no more in the form of spiritual and moral education. According to (Mohd Noor, 2015), the extremist movements carried out by the ISIS are targeting the Islamic learning centers and tahfiz institutions, with the intention to make these education centers as the place to spread da'wah. They used the term jihad in their study modules which is said to be 
contrary to the real concept of jihad. According to (Nur Rosidah, 2012) in her article entitled 'Fundamentalisme Agama', fundamental groups exercise extreme action by taking several pieces of Qur'anic verse in general without conducting thorough studies on the reason and causes in which those verses are sent down for guidance. This will indirectly lead to violence and terrorism that can endanger the public lives.

\section{CONCLUSION}

The ISIS movement has successfully spread the ideology and radical thinking to all over the world including Malaysia through various mediums including online medium. The ISIS militant group utilizes internet technology and social media for the purpose of spreading messages and attracting the world community especially youths to support their organization. Many of them have migrated to the Middle East to join in the battle along with other jihadists by using violence and radicalism. It is therefore proven that media is very significant in influencing the involvement of youth in the ISIS movement in Malaysia. To worsen the situation, the improvement of technology has enabled the internet users to disseminate information and allow them to connect with other users without borders and restrictions.

\section{ACKNOWLEDGMENT}

Special thanks to the Malaysia Ministry of Higher Education and Universiti Sultan Zainal Abidin (UniSZA) for supporting this research under the Fundamental Research Grant Scheme (FRGS) RR 209.

\section{CORRESPONDING AUTHOR}

Fadzli Adam, Professor at Research Institute for Islamic Products and Malay Civilization, Universiti Sultan Zainal Abidin (UniSZA), Kampus Gong Badak, 21300 Kuala Nerus, Terengganu, Malaysia.

Email: fadzliadam@unisza.edu.my

\section{REFERENCES}

Zin, A.M. (2017). Fitnah Media Sosial Cetus Permusuhan dan Kehancuran Ummah: Perspektif Fiqh Tabayyun. Fiqh Tabayyun: Mendepani Cabaran dan Fitnah Media Sosial. Putrajaya: Institut Wasatiyyah Malaysia.

Adam, F., \& Muhad, F. . (2017). 498602-d.pdf. In ISER International Conference (pp. 5-11).

Adam, F., Muhad, F. N., Wahid, N. A., \& Mansor, S. A. (2017). Malaysia Concept of Muhibbah: Proposed Solution towards the Myanmar's Ethnic and Religious Crises. In Proceedings of International Conference of Empowering Islamic Civilization (pp. 7-8).

Adam, F., Muhad, F. N., Wahid, N. A., Mansor, S. A., Yusoff, Z., Omar, S. H. S., ... Salleh, M. A. (2017). Myanmar's Religious Crises: Proposed Solution through the Concept of Muhibbah. International Journal of Academic Research in Business and Social Sciences, 7(8), 197-203. https://doi.org/10.6007/IJARBSS/v7-i8/3221

Alazzany, M. A. O. A. (2008). A Critical Discourse Analysis of the Representation of Islam and Muslims following the 9/11 Events as Reported in the New York Times (Unpublished Ph.D. thesis). Universiti Putra Malaysia, Serdang. 
INTERNATIONAL JOURNAL OF ACADEMIC RESEARCH IN BUSINESS AND SOCIAL SCIENCES

Vol. 8, No. 11, Nov, 2018, E-ISSN: 2222-6990 @ 2018 HRMARS

Berger, J. (2014). How ISIS Games Twitter. The Atlantic. Retrieved 14 October 2016, from http://www.theatlantic.com/international/archive/2014/06/isis-iraq-twitter-social-mediastrategy/372856/.

Bräuchler, B. (2004). Islamic radicalism online: the Moluccan mission of the Laskar Jihad in cyberspace. The Australian Journal of Anthropology, 267-285.

Crilley, K., (2001). Information warfare: New battlefields terrorists, propaganda and the Internet. Aslib Proceedings, 53, 7, 250-264.

Gorawantschy, B., Gunaratna, R., Sarmah, M \& Rueppel, P. (Eds.). (2016). Countering Daesh Extremism: European and Asian Responses. Singapore: Konrad Adenauer Stiftung.

Greene, K. J. (2015). ISIS: Trends in terrorist media and propaganda. International Studies Capstone Research Papers Paper 3. Ohio, United States: Cedarville University.

Hannigan, R. (2014, November 3). The web is a terrorist's command-and-control network of choice. Retrieved from Financial Times: http://www.ft.com/cms/s/2/c89b6c58-6342-11e4-8a63 00144feabdc0.htmI\#axzz46IxIAMjp.

Hogan, J. (2005). The psychology of terrorism. London: Routledge.

Jacobson, M., (2010). Terrorist financing and the internet. Studies in Conflict and Terrorism, 33, 4, 353-363.

Justin, M. (2010). Generation $Y$ in the Work Force: Managerial Challenges, The Journal of Human Resource and Adult Learning, 6(1), 68-78.

Juergensmeyer, M. (2017) Terror in the Mind of God: The Global Rise of Religious Violence (4th ed.). California: University of California Press.

Kanade, N. (2016). Tracing Islamic Extremist Ideologies: The Historical Journey of Jihad form the Late Antique Period to the 21st century (Unpublished Senior Thesis, Claremont Colleges, California, LA).

Mahan, S., \& Griset, P. L. (2013). Terrorism in Perspective (3rd ed.). London: Sage.

Malaysiandigest.com, (2016). Retrieved from http://www.malaysiandigest.com/bahasamalaysia/590749-keganasan-bukan-jihad.html.

Marcu, M., \& Balteanu, C. (2014). Social media-a real source of proliferation of international terrorism. Annales Universitatis Apulensis: Series Oeconomica, 16(1), 162-169. Retrieved from

http://search.proquest.com.ezproxy.libproxy.db.erau.edu/docview/1555353946?accountid= $\underline{27203}$

Maniscalco, P. \& Christen, H.T. (2001). Understanding Terrorism and Managing the Consequences. Prentice Hall Publishing, Upper Saddle River, NJ 07458.

Mielach, D. (2012, January 9). Terrorists Seek Out 'Friends' on Facebook. Retrieved from http://www.businessnewsdaily.com/1877-terrorist-social-media.html.

Mohd Nasir, B. (2011). The influence of Middle East Islamic movement on the extremist thought in Malaysia. International Journal for Historical Studies, 3(1), 31-46.

Mohd Noor, M. R. (2015). Ektremisme Rentas Agama dan Tamadun. Kuala Lumpur: Universiti Malaya. Muhad, F. N., Adam, F., Wahid, N. A., Salimah, N., Mansor, A., Mujani, W. K., ... Rahimah, E. (2017). Myanmar's Religious and Ethnic Crises Response : The Efficiency of Replicating Medina' $s$ Constitution. International Journal of Academic Research in Business and Social Sciences, 7(7), 
INTERNATIONAL JOURNAL OF ACADEMIC RESEARCH IN BUSINESS AND SOCIAL SCIENCES

Vol. 8, No. 11, Nov, 2018, E-ISSN: 2222-6990 @ 2018 HRMARS

801-808. https://doi.org/10.6007/IJARBSS/v7-i7/3152.

Nur Rosidah. (2012). Fundamentalism agama. Walisongo: Jurnal Penelitian Sosial Keagamaan, 20(1), 1-24.

Ogun, M.N., (2012). Terrorist Use of Internet: Possible Suggestions to Prevent the Usage for Terrorist Purposes. Journal of Applied Security Research 7, 2, 203-217.

Pew Research Center, "Social Networking Fact Sheet," (January 2014). Accessed April 23, 2015. http://www.pewinternet.org/fact-sheets/social-networking-fact-sheet/.

Portal Rasmi Fatwa Malaysia. (2014). Isu umat Islam Malaysia berjuang atas nama ISIS. Diakses pada 21 Oktober 2015, dari http://www.e-fatwa.gov.my/fatwa-kebangsaan/isu-umat-Islammalaysia-yang- berjuang-atas-nama-isis-0.

Prensky, M. (2001.). Digital Native, Digital Immigrants. On the Horizon, 9(5), 1-6.

Sauffiyan, A., Hassan, A. B. U., \& Influence, S. M. (2016). Daesh: Kebangkitan Dan Pengaruh Media Sosial, 32(2), 381-404.

SuaraTV (Mac, 2015).http://www.suara.tv/2015/03/05/jumlah-rakyat-malaysia-sertai-militan-ismeningkat/.

Tambunan, F. P. M. (2014). Sejarah dan Ideologi ISIS (Islamic State of Iraq and Sham), (Unpublished master thesis, Universitas Indonesia, Jakarta.

Walsh, B. (2015, June 14). Online Jihad: ISIS and social media. Retrieved from Brock Walsh: https://brockwalsh.wordpress.com/2015/06/14/isis-and-social-media/.

Wan Hamat, W. N., Hussin, Z., Mohamed Yusoff, A. F., \& Sapar, A. A. (2013). Pengaruh media massa terhadap penampilan akhlak pelajar Islam Politeknik Malaysia. The Online Journal of Islamic Education, 1(1), 17-27.

Weimann, G., (2008). The psychology of mass-mediated terrorism. American Behavioral Scientist 52, 1, 69-86.

York, R. (2015). Know the enemy: Islamic State of Iraq and Levant. Lulu.com. 